\title{
DIAMOND PROSPECTIVITY FROM INDICATOR MINERALOGY: A WESTERN AUSTRALIAN PERSPECTIVE.
}

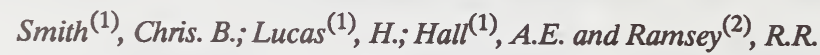 \\ (1) CRA Exploration Pty. Ltd., 21 Wynyard St., Belmont, Western Australia 6104; \\ (2) University of Western Australia, Hackett Drive, Crawley, Western Australia.
}

Since the first discovery of kimberlite in South Africa, over 100 years ago, it has been the desire of explorationists to devise a rapid scheme for establishing whether a particular find was diamond bearing or not, without recourse to costly bulk sampling.

The recognition of distinctive compositions of resistate minerals associated with diamond such as sub-calcic (G10) garnets by Gurney and Switzer (1973) and Sobolev (1974) was one of the first steps in establishing such an appraisal system. Various workers have correlated the presence and abundance of diamond with the chemistry of ilmenite (Fesq et al, 1976) and chromite (Sobolev, 1974), and the methods were further developed by Gurney (1984) and by Moore and Gurney (1989) whose outline represents the sophisticated state of diamond grade prediction today. The latter authors use the soda content of eclogitic garnets as a predictor of eclogitic diamond grade and the chemistry of sub-calcic chrome pyropes along with high chrome chromite to emphasise the importance of the harzburgitic paragenesis for peridotitic diamond formation. High-chrome magnesian ilmenites are empirically correlated with high diamond grade, a relationship speculated by the authors as reflecting low oxygen fugacities within the kimberlite magma during upward transportation from the mantle source. Low oxygen fugacity should favour retention of unresorbed diamond, and therefore the ilmenite composition can be used as a diamond preservation predictor for both styles of diamond paragenesis.

Concentrates from kimberlites of the North and East Kimberley of Western Australia (Jaques et al., 1986; Lucas et al., 1989) are characterized by an abundance of megacrystal ilmenite and subordinate garnet, which ranges in composition from titanium pyrope of megacrystal or sheared lherzolite paragenesis to peridotitic chrome pyrope. Sub-calcic garnets are present in small quantities, indicating a depleted component in the mantle and hence a potential for peridotitic diamond paragenesis. Eclogitic garnet is present but in such low numbers as to limit its usefulness in predicting grade. As only a few of the kimberlites carry magnesio-chromites with $\mathrm{Cr}_{2} \mathrm{O}_{3}$ values typical of diamond inclusions, the diamond contribution from the spinel harzburgite paragenesis in these kimberlites is thought to be insignificant.

Many North Kimberley kimberlites, e.g. Hadfields and Pteropus, carry ilmenites with high $\mathrm{Cr}_{2} \mathrm{O}_{3}$ and $\mathrm{MgO}$ which indicate good potential for diamond preservation, but the general lack of associated G10 garnets or high chrome chromites implies an insignificant diamond contribution from the harzburgitic parageneses so the overall predicted grade is poor. In general there is good agreement between actual and predicted grade. 
Most lamproites from the West Kimberley and Argyle contain little mantle derived garnet and are practically devoid of megacrystal magnesian ilmenite (Jaques et al., 1986; Lucas et al., 1989; Moore and Gurney, 1989). Most concentrate ilmenites recovered are $\mathrm{Mg}$-poor Mn-bearing groundmass types which cannot be used in diamond grade predictions. The poor representation of eclogitic minerals in concentrates restricts their use in predicting grade and belies the importance of the eclogitic diamond paragenesis at Ellendale and especially at Argyle. Carbon isotope and diamond inclusion work by Jaques et al. (1989) show chat roughly $96 \%$ of the Argyle stones and nearly half of those from Ellendale come from eclogites.

The lherzolitic mineral suite is prominent within the peridotite diamond paragenesis in Australian lamproites, unlike the African and Siberian situation where the harzburgitic suite is pre-eminent. This is shown by frequent chrome diopside inclusions within diamond (Jaques et al., 1989) and indirectly confirmed by concentrate mineralogy which, while containing lherzolitic garnets, commonly lacks the sub-calcic varieties. Interestingly, amongst the Ellendale pipes, the most diamondiferous does not contain the most sub-calcic garnets. As yet, no sub-calcic garnets have been found in Argyle concentrate (Lucas et al., 1989), the richest diamond bearing lamproite of all. High-chrome chromites with $\mathrm{Cr}_{2} \mathrm{O}_{3}>60 \%$ and MgO>12\% are present in both the diamondiferous and weakly diamondiferous pipes and may represent a chromite harzburgite diamond paragenesis as suggested by Moore and Gurney (1989).

In conclusion, Moore and Gurney's rules so successfully used in Africa and north America are effective for the Western Australian kimberlites where the dominant source of diamond paragenesis appears to be depleted harzburgite from the diamond stability field. As these authors themselves warn, the appraisal scheme meets with less success in estimating the diamond bearing potential of lamproites. One problem with lamproites is the paucity of eclogitic minerals in the concentrates which prevents proper assessment of the contribution from the dominant eclogitic paragenesis of the Australian lamproite diamonds.

Three other short comings of the scheme have become apparent on applying it to the Australian situation. Firstly the assumption that the dominant peridotitic diamond paragenesis is harzburgitic is not necessarily true. It is not the case at Argyle or at Ellendale where the lherzolitic paragenesis is as important, if not more so. Secondly Glo garnets, indicative of depleted harzburgitic upper mantle, need not necessarily come from the diamond stability field (Boyd and Nixon, 1989; shee et al., 1989) and hence may be unreliable diamond predictors. This is shown by the presence of G10 garnets at the barren North Kimberley occurrence of skerring. The development and use by Griffin (1990) of a garnet-Ni thermometer, which suggests Skerring peridotitic garnets (G10s included - Griffin, pers. comm.) are either too cold or too hot to be associated with a lithospheric source of diamond, may be the next refinement to the scheme for predicting diamond grade from. indicator mineral chemistry. Thirdly, the role of ilmenite chemistry in predicting diamond preservation is not clear. This certainly seems to be the case at Skerring where ilmenite chemistry is invoked to remove "non existent" diamonds. Also at Argyle the diamonds are highly resorbed yet the high chrome-bearing magnesian ilmenite chemistry predicts little resorption. 


\section{REFERENCES :}

Boyd, F.R., and Nixon, P.H., 1988. Low-Ca garnet harzburgites: origin and role in craton structure. Geophysical Laboratory, Carnegie Institute of Washington, Annual Rept., 1987-88, p. 8-13.

Fesq, H.W., Kable, E.J.D., \& Gurney, J.J., (1976) The geochemistry of some selected South African kimberlites and associated heavy minerals. National Institute for Metallurgy. South Africa. Report No. 1703.

Griffin, W.I. (1990) The nickel thermometer: A new tool for diamond exploration. CSIRO Division of Exploration Geoscience, Exploration Research News 4, p. 3-4.

Gurney, J.J., and Switzer, G.S., (1973) The discovery of garnets closely related to diamonds in the Finsch Pipe, South Africa. Contrib. Mineral. Petrol., vol.39, p. 103-116.

Gurney, J.J., (1984) A correlation between garnets and diamonds in kimberlites. In J.E. Glover and P.G. Harris, Eds.,.Kimberlite Occurrence \& Origin, University of Western Australia, Geology Dept. Publ. 8, p. 143-166

Jaques, A.L, Lewis, J.D., and Smith, C.B., (1986) The kimberlites and lamproites of Western Australia. Geol. Surv. Western Australia, Bull. 132, 268 p.

Jaques, A.L., Hall, A.E., Sheraton, J.W., Smith, C.B., Sun, SS., Drew, R.M., Foudoulis, C., and Ellingsen, K., (1989) Composition of crystalline inclusions and C-isotopic composition of Argyle and Ellendale diamonds. In J. Ross, Ed., Kimberlites and Related Rocks, Volume 2, Their Mantle/Crust Setting, Diamonds and Diamond Exploration. Geological Society of Australia Special Publication No. 14, Blackwell, Melbourne, p. 966-989.

Lucas, H., Ramsay, R.R., Hall, A.E., Smith, Chris B., and Sobolev, N.V., (1989) Garnets from Western Australian kimberlites and related rocks, In J. Ross, Ed., Kimberlites and Related Rocks, Volume 2, Their Mantle/Crust Setting, Diamonds and Diamond Exploration. Geological Society of Australia Special Publication No. 14, Blackwell, Melbourne, p. 809-819.

Moore, R.O., and Gurney, J.J., (1989) The development of advanced technology to distinguish between diamondiferous and barren diatremes. Geol. Surv. of Canada Open File Report 2124, part 1, p. 1-90.

Shee, S.R., Bristow, J.W., Bell, D.R., Smith, C.B., Allsopp, H.L., and Shee, P.B., (1989) The petrology of kimberlites, related rocks and associated mantle xenoliths from the Kuruman Province, South Africa, In J. Ross, Ed., Kimberlites and Related Rocks, Volume 1, Their Composition, Occurrence, Origin and Emplacement. Geological Society of Australia Special Publication No. 14, Blackwell, Melbourne, p. 60-82.

Sobolev, N.V., (1974) Deep seated inclusions in kimberlites and the problem of the composition of the upper mantle. Translated by D.A. Brown, 1977, AGU, Washington, 279 p. 